\title{
An empirical relationship between company growth and the market price of securities listed on the Johannesburg Stock Exchange
}

\author{
Narendra Bhana \\ Graduate School of Business, University of Durban-Westville, Durban 4000, Republic of South Africa
}

\begin{abstract}
There appears to be a widespread belief among investors that growth companies and growth stocks are identical. The objective in this article is to determine if the shares of high growth companies listed on the Johannesburg Stock Exchange (JSE) provided superior investment returns during the period 1974-88. The empirical evidence revealed that high growth companies underperform because the market overestimates their future growth and future return on equity, as a result their shares tended to have overvalued price-earnings ratios. Therefore, the investor will incur substantial losses if their results are below expectations. It is hypothesized that a cognitive bias may be responsible for the erroneous identification of growth stocks as shares of growth companies. Company results have a tendency to regress to the mean as the underlying economic forces attract new entrants to attractive markets and leave low-growth businesses. Because of this tendency, companies that have provided high growth in the past may prove to be inferior future investments. Past financial attributes cannot be relied upon to predict future returns. The investor should integrate a rigorous valuation model into the share selection procedure so that estimates of future growth and profitability can be used to make an estimate of expected returns.
\end{abstract}

Dit blyk dat daar ' $n$ algemene mening onder beleggers bestaan dat groeiende maatskappye en groeiende effekte oen en dieselfde is. Die doel van hierdie ondersoek is om te bepaal of die aandele van maatskappye wat op die Johannesburgse Effektebeurs genoteer word en wat 'n hoë groei toon, hoër opbrengste gelewer het gedurende die tydperk 1974-88. Die empiriese bevindings dui daarop dat hoëgroeimaatskappye onderpresteer, omrede beleggers hul toekomstige groei en toekomstige opbrengste oorskat, met die gevolg dat hul aandele oorgewaardeerde prysverdienste-verhoudings toon. As gevolg hiervan strek dit tot nadeel van die belegger as die uitslae nie aan die verwagtings voldoen nie. Die hipotese word gemaak dat 'n bewussynsvooroordeel moontlik daarvoor verantwoordelik is dat groei-aandele foutiewelik as aandele van groeiende maatskappye geïndentifiseer word. Maatskappy-uitslae het die neiging om terug te keer tot die gemiddelde, na gelang die onderliggende ekonomiese kragte nuwe deelnemers na aantreklike markte lok, weg van laegroeimarkte. As gevolg van dié neiging mag maatskappye wat in die verlede hoë groei getoon het, swak toekomstige beleggings wees. Daar kan dus nie op voormalige finansiële kenmerke vertrou word om toekomstige opbrengste te voorspel nie. Die belegger behoort ' $n$ streng skattingsmodel in sy keuse van effekte te integreer sodat skattings van toekomstige groei en winsgewendheid gebruik kan word om 'n skatting van verwagte opbrengste te maak.

\section{Introduction}

Traditional investors seek growth companies in the belief that they represent good investments. Growth companies have received much attention in recent years, resulting in the term becoming an economic cliché. Whether it is management leadership, national importance, or simply prudent investment that one seeks, the selection process is always the same: look to the growth company. There appears to be a widespread belief among investors that growth companies and growth stocks are identical. Are growth stocks the shares of growth companies? Empirical evidence suggests that the opposite is true. There appears to be a persistent tendency for shares of growth companies to provide lower returns than shares of companies lacking growth opportunities. The purpose of this article is to demonstrate that the shares of a company do not necessarily have the same characteristics as the company, and that growth stocks are a haphazard category of investments whose relationship, curiously enough, has little or nothing to do with growth companies. It will be demonstrated that a cognitive bias may be responsible for the erroneous identification of growth stocks as shares of growth companies.

\section{Previous studies}

Bernstein (1956) analyzed the financial performance of a sample of companies regarded as growth companies by investment analysts and institutional investors. It was noted that the superior investment performance of a growth company is not a fortuitous outcome of being a member of a growth industry. The ability to create its own market is the strategic, the dominating, and the single-most distinguishing characteristic of a true growth company. It was shown that merely relying on past investment performance can be misleading when it comes to the selection of individual shares likely to provide superior returns. Bemstein (1956: 94) recommends that qualitative analysis must also be undertaken to explore the special circumstances and characteristics which are crucial for superior performance. That is, whether it dynamically creates its own markets; has quasi-monopolistic features reflected in higher profit margins; is sufficiently innerdirected to be relatively immune to business fluctuations; and has turned in a consistent record of growth in eaming power, dividends, and retum on net worth.

Bernstein suggests that there are two parts to this task of selecting shares providing superior investment returns. The investor must satisfy himself (1) that the company is likely to continue to grow in earning power, and (2) that the share is priced relatively low enough at the time of purchase so the increase

greater value to the investor. A statistical analysis of the market price of the share is crucial to determine whether it is a good investment in the sense of not being valued so high that in effect the results of future growth are already discounted. In investing, nothing beats the discovery of undervalued

trend in earnings. But simply purchasing so-called growth stocks tends to lead to the selection of overvalued securities. 
Reilly (1971) demonstrated that it is crucial for investors to make a differentiation between types of companies and types of shares. The designation (e.g., growth company) accorded to a company is principally determined internally by the investment decisions of the firm (what assets they own) and by the operating and financial philosophy of the firm's management. When a company invests in assets (whether human or physical), it thereby determines its characteristics and accepts the accompanying risks and opportunities. At the same time, two different sets of management can obtain substantially different results with the same set of assets. Management's operating and financial decisions can influence not only the expected flow of earnings, but also the risk inherent in it. Therefore, it is necessary to consider the assets of the firm, what the corporate management is capable of doing with these assets, and what they intend to do with them. Finally, these company factors should be compared to similar factors for all other companies to determine the firm's relative position in the universe of all companies.

Reilly (1971) further demonstrated that the share of a company does not necessarily have the same characteristics as the company. The type of share is determined externally, by how investors perceive the expected performance of the firm and how they adjust share prices to account for these perceptions. Therefore, the type of share is determined by comparing the expected return and the uncertainty of the returns for a particular share to these same measures for all other available shares. Consequently, there can be differences between the designation given a particular company and the designation given the shares that company has issued. Reilly (1971: 43) concludes that the investor should have an opinion about the type of company he is dealing with - is it a cyclical company, a speculative company, or a growth company? After analyzing the company it is necessary to consider the characteristics of the company's shares. The type of company and the type of shares may not necessarily be the same.

Peters \& Waterman Jr. (1982) published a bestseller entitled In search of excellence. This book profiled companies that had been identified as 'excellent' on the basis of outstanding financial performance as ranked by several measures of profitability and growth. Clayman (1987) investigated the same companies and found that their financial performance began to decline virtually across the board, starting right from the date on which they were selected as 'excellent'. Furthermore, a group of 'unexcellent' companies ranked at the bottom by the same ratios showed widespread improvement in performance over the next five years. Clayman (1987:59) concluded that the majority of excellent companies underperformed because the market overestimated their future growth and future return on equity and, as a result, the market valuation of such companies tends to be overly optimistic. Therefore, the investor will incur substantial losses if their results are below expectations.

Solt \& Statman (1989) investigated the relationship between company growth and the performance of the company's equity shares. It was shown that, on average, the more the growth opportunities of a company at a given time, the lower the risk-adjusted return that its share provides to shareholders in the subsequent period. Furthermore, it was shown that identification of superior historical financial attributes does not ensure either superior future earnings or investment returns.

\section{Company growth measured by Tobin's $q$}

By definition, growth companies are expected to provide above-average growth opportunities in the future. The growth of a company is usually measured in terms of accounting data. As a result of distortions caused by tax laws and arbitrary accounting conventions, the use of accounting data to measure company growth has been extensively criticized (Fischer \& McGowan, 1983). Future growth, on the other hand, will be appropriately capitalized by an efficient capital market. By combining capital market data with accounting data, a more accurate measure of company growth can be derived. Tobin's q provides the framework for this construct. Relying on capital markets to value growth avoids or substantially mitigates most of the shortcomings inherent in using accounting data only as a measure of growth. We measure the growth opportunities of a company by its Tobin's q i.e. the ratio of the company's market value to the replacement value of assets (Tobin, 1969).

Lindenberg \& Ross (1981) show that Tobin's q measures the capitalized values of growth opportunities attributable to both monopoly and company-specific factors. It is the ratio of the market value of the company to the replacement value of the company's assets. Tobin's q should be 1.0 for companies with no growth opportunities, increasing as the value of growth opportunities increases. For example, a company in a monopolistic position may have a Tobin's q of 2.75 . Of the $2.75,1.0$ reflects the replacement value of assets. The remainder, 1.75, reflects the capitalized value of growth opportunities. Similarly, the Tobin's $q$ for a company in a declining industry may be 0.80 . This ratio is lower than 1.0 because the average market value of the company is lower than the replacement value of the assets. A ratio that is lower than 1.0 indicates that a company should not replace its assets as they become obsolete.

Employing $q$ as a measure of future growth prospects indicates that the higher the $\mathrm{q}$ value the more desirable the investment environment. If $\mathrm{q}$ is equal to 1.0 , as it would be in an idealized world, the return on financial claims is equal to the return on real assets. If $q$ is greater than 1.0 , the return on financial claims are greater, and vice versa if $q$ is less than 1.0. Hence, industry sectors with a large $q$ would indicate a more favourable investment climate, and funds will flow to those sectors of the economy. Therefore, one would anticipate a high positive correlation between industry investment and q. The empirical evidence presented by Malkiel, Von Furstenberg \& Watson (1979) shows that the rate of investment undertaken by companies with high Tobin's $q$ to be higher than that by companies with low q's.

\section{Research data}

Lindenberg \& Ross (1981) provide a detailed computational procedure for estimating the Tobin's q of companies using publicly available data. The same procedure has been used in this investigation. Tobin's $q$ is a measure of a company's growth opportunities, whose precise value can be obtained only rarely. The $q$ values used in this investigation are 
estimates of true values, based on publicly available data. The market value of the company is estimated as the sum of the values of its securities, which fall into three broad groups: (1) ordinary shares, (2) preference shares, and (3) debentures.

Replacement value is the monetary outlay needed to purchase the current productive capacity of the company at minimum cost and with the most modern technologies available. The estimate of the replacement value of a company's assets is based on assumptions about rates of technical advances over time, the relationship between real depreciation and book depreciation, and the applicability of an aggregate price index to individual companies. Estimates of replacement values are based on data that are not updated monthly. Moreover, replacement value estimates are not likely to be very sensitive to month-to-month changes in market values. Therefore, end-of-year replacement value estimates suggested by Lindenberg \& Ross (1981) was used.

A random sample of 50 companies listed on the JSE during the fifteen-year period 1974-1988 was selected to provide the empirical evidence. For each company in the random sample monthly data on share prices, number of issued shares, monthly share returns, and the corresponding return on JSE Overall Actuaries Index was collected. The monthly data was obtained from the database of the JSE and the Bureau of Financial Analysis of the University of Pretoria. Details of the replacement values of assets were obtained from the published financial statements of the companies concerned. However, the majority of companies did not provide replacement values of assets in their financial statements. The assets of these companies were restated by using the Consumer Price Index (CPI) covering the period in question.

\section{Research methodology}

Each company in the sample was ranked by Tobin's $q$ from high to low values for each year $T(T=1974,1975, \ldots$ 1988), then assigned to five quintiles, where $q_{1}$ is the quintile including the companies with the highest $q$ in year $T$, and $q_{s}$ is the quintile including companies with the lowest $q$ in year $T$. The fifteen $q_{1}$ portfolios were merged to form portfolio $P 1$ representing shares with the highest value of $q$. This process was repeated for portfolios P2, P3, P4, and P5. Portfolio P5 will represent shares with the lowest value of $q$. The average relationship between Tobin's $\mathrm{q}$, as well as the market value of equity and the earnings yield was calculated for each of the five portfolios.

To oblain a relationship between company growth and the risk-adjusted returns on equity shares, the Market Model developed by Bowman (1983) is used:

$E R_{i t}=\left(R_{i t}-R_{f i}\right)-\beta_{i}\left(R_{m t}-R_{f t}\right)$

where:

$\mathrm{ER}_{\mathrm{it}}$ is the excess return on share $\mathrm{i}$ during month $\mathrm{t}$;

$R_{i t}$ is the return on share $i$ during month $t$;

$\beta_{i}$ as the beta of share $i$ estimated using twelve monthly observations during the preceding year;

$\mathrm{R}_{\mathrm{ft}}$ is the risk-free rate during month $\mathrm{t}$; and

$R_{m t}$ is the return on the JSE Overall Actuaries Index during month $\mathrm{t}$.
Portfolios were formed based on Tobin's $q$ at the end of December of each year $T$. The weight of each share in the portfolio is proportional to its market value of equity at the end of December. Portfolio compositions and weights were modified once a year at the end of December. Excess returns for year $T+1$ are defined as the means of its monthly excess returns. Monthly excess returns were calculated for the previously defined portfolios P1, P2, P3, P4, and P5. A statistical analysis (T-Statistic) was performed to determine if shares of high growth companies (high Tobin's q) provided higher/lower retums than shares of companies lacking growth opportunities (low Tobin's q).

\section{Emplrical results}

The results appearing in Table 1 reveal that there is a positive reiationship between Tobin's $q$ and the market value of equity and also a positive relationship between Tobin's $q$ and the price-earnings ratio of the company shares (i.e., a negative relationship between Tobin's $q$ and earnings yield). The positive relationship between Tobin's $q$ and the priceearnings ratio suggests that this ratio serves as a proxy for growth opportunities. This relationship is not surprising, as Miller \& Modigliani (1961), and Smalter \& Lancy (1966) have long since demonstrated that growth opportunities are a major determinant of the price-earnings ratio. Similarly, the positive relationship between Tobin's $q$ and the market value of equity suggests that the latter also serves as a proxy for growth opportunities (see Table 1).

The positive relationship between market value of equity and Tobin's q seems surprising, as it seems to imply that the typical large company is a growth company. This is contrary to the conventional wisdom that small companies predominate among growth companies. The use of the market value of equity as a measure of company size may be inappropriate as the market value is influenced by market rating. Book value of assets and number of employees are more reliable than market value of equity as a measure of company size.

In Table 2 is presented the mean monthly excess returns over the entire fifteen-year period for the five portfolios representing different $q$ values. It can be seen that $P 1$, the portfolio containing the shares of companies with the highest

Table 1 Medians of Tobin's q, market value of equity, and earnings yield for portfolios ranked by Tobin's $q$ for the years 1974-1988

\begin{tabular}{lccc}
\hline \multicolumn{1}{c}{ Portfolio } & $\begin{array}{c}\text { Median } \\
\text { Tobin's } q\end{array}$ & $\begin{array}{c}\text { market value } \\
\text { (R millions) }\end{array}$ & $\begin{array}{c}\text { Median } \\
\text { eamings yield }\end{array}$ \\
\hline P1 (shares with the highest q) & 2.75 & 721.3 & 0.057 \\
P2 & 1.90 & 545.2 & 0.079 \\
P3 & 1.51 & 327.6 & 0.092 \\
P4 & 1.14 & 275.1 & 0.102 \\
P5 (shares with the lowest q) & 0.73 & 114.5 & 0.113 \\
\hline
\end{tabular}

Note:

values, eamings yield, and q of constituent securities for each of the fifteen years investigated are pooled. The statistics are based on these inter-temporally pooled distributions. 
Table 2 Monthly access returns (\%) for Tobin's q over the year following the formation of each portfolio for the years 1974-1988

\begin{tabular}{lcc}
\hline \multicolumn{1}{c}{ Portfolio } & $\begin{array}{c}\text { Mean monthly } \\
\text { excess returns }\end{array}$ & T-statistic \\
\hline P1 (shares with the highest q) & -0.20 & $-3.35^{\circ}$ \\
P2 & -0.08 & -1.12 \\
P3 & 0.14 & $2.48^{\mathrm{b}}$ \\
P4 & 0.28 & $5.41^{\circ}$ \\
P5 (shares with the lowest q) & 0.32 & $5.33^{\circ}$ \\
\hline a $\quad$ significantly different from zero at the 0.01 level (two-tail test). \\
b = significantly different from zero at the 0.05 level (two-tail test). \\
\hline
\end{tabular}

Tobin's q, yielded negative excess returns of $0.20 \%$ per month. Portfolio P5, containing the shares of the companies with the lowest $q$, had positive excess returns of $0.32 \%$ per month. In other words, shares of growth companies (high Tobin's q) provided lower returns than shares of companies lacking growth opportunities. The difference in returns between portfolios Pl and P5 is $0.52 \%$ per month, or $6.4 \%$ per year if the monthly rates are compounded (see Table 2).

Shares of growth companies tend to provide below-average returns in the future. How can one explain these disappointing results from supposedly excellent companies that provided superior returns in the past? One possible reason is that possession of certain financial and behavioural attributes in the past in no way ensures future superior performance. There is a phenomenon in nature referred to as 'reversion to the mean', which asserts that, over time, properties of members of groups tend to converge to the average value for the group as a whole. This concept is widely applicable in situations where economic forces tend to move things towards equilibrium. In the world of finance, researchers have shown that returns on equity tend to revert to the mean (Keim \& Stambaugh, 1986). Economic theory suggests that markets that offer high returns will attract new entrants, who will gradually drive returns down to general market levels.

Another possible reason for the poor performance of high growth companies is that the share market overestimates their future growth and future returns, and, as a result, their shares are overvalued. Therefore, the investor will incur substantial losses if their results are below expectations. By definition, a growth stock is a share possessing superior return capabilities when compared to other shares in the market with similar risk characteristics. This superior return is due to the share being undervalued at a given point in time relative to other shares in the market. If the share is undervalued, its price should increase to reflect its true intrinsic value when the correct information becomes available. During the period in which the share changes from an undervalued security to a properly valued security, returns will exceed the market average, and the share will be considered a growth stock.

A future growth stock is basically a currently undervalued share that has a high probability of being properly valued in the near term. This means that growth stocks are not necessarily limited to growth companies. If investors recognise a growth firm and discount the future earnings stream properly, the current market price will reflect the future growing earning stream. The investor who acquires the share at this 'correct' market price will receive only the market rate of return, even when superior earnings growth is attained. If investors overprice the share of a growth company and an investor pays the inflated price, his returns will be below the risk-adjusted normal retum. A future growth stock can be issued by any type of company; it is only necessary that the share has not been properly valued by the market at a given point in time.

When a share is overpriced, there is a high probability that, in the future, when the market adjusts the share price to its true value, there will be either very low or possibly negative rates of return on it. This might be the case for an excellent growth company whose share is selling at an extremely high price-earnings ratio reflecting a belief that outstanding growth will continue for a substantial period in the future. If there is any reduction in growth pattern, or any disruption in growth, this price-eamings ratio can drop rapidly and substantially. Therefore, there is a strong likelihood of a substantial decline if everything does not conform to the most optimistic expectations. An overpriced share of a growth company can be considered to be speculative.

An important conclusion from the empirical evidence is that the term 'growth stock' is meaningless. A growth stock can be identified only with hindsight - it is simply a share that provided superior returns in the past. But the concept of 'growth company' can be used to identify the most creative and most imaginative management groups; and if, in addition, their shares are valued at a reasonable ratio to their increase in earning power over a period of time, the prognosis for superior future investment performance is favourable.

\section{Cognitive bias in selecting shares of growth com- panies for investment}

The tendency of decision-makers to follow conventional thinking could be a result of a cognitive bias. The most general conclusion obtained from the numerous investigations of the psychology of uncertainty is that people do not follow the principles of probability theory in judging the likelihood of uncertain events. This conclusion is hardly surprising because many of the laws of probability are neither intuitively apparent, nor easy to apply. Less obvious, however, is the fact that the deviations of subjective from objective probability seem reliable, systematic, and difficult to eliminate. Apparently, decision-makers replace the laws of probability with heuristics which sometimes yield reasonable estimates and quite often do not.

Kahneman \& Tversky (1972) suggest that cognitive bias could arise from a heuristic called representativeness. A person who follows the representativeness heuristic evaluates the probability of an uncertain event by the degree to which it is (1) similar in essential properties to its parent population, and (2) reflects the salient features by which it is generated. Ordering of events according to representativeness appears to be widespread, and people consistently judge the more representative event to be more likely whether it is or not. Representativeness may play an important role in many probability judgments including investment decisions. Kahneman \& Tversky support this hypothesis with a series of experiments. 
In one experiment Kahneman \& Tversky (1982) presented subjects with a brief personality sketch of Linda. The description of Linda was constructed to be similar to or representative of the profile of an active feminist and unrepresentative of that of a bank teller. The outcome of this experiment was consistent with the hypothesis that subjects judge the probability of an event by its similarity or representativeness. Specifically, because the feminist attitude seems more representative of Linda than the bank-teller occupation, subjects concluded that it is more probable that Linda is a bank teller and feminist than just a bank teller.

The representativeness heuristic hypothesis can be used to explain the confusion between growth companies and growth stocks. According to this hypothesis investors overestimate the probability that the shares of a growth company is a growth share because they rely on the representativeness heuristic. Specifically, they overestimate the probability that a growth stock is a share of a growth company because a growth stock is perceived to be similar to a growth company.

Kahneman \& Tversky (1982) investigated another heuristic called availability. According to this heuristic one judges the probability of an event by the ease with which relevant instances are recalled or imagined. More specifically, the number of relevant instances that could be readily retrieved or the ease with which they come to mind are major clues that decision-makers use in estimating probability or frequency. The respondents were asked if words containing three or more letters are more likely to start with a ' $K$ ', or have a ' $K$ ' in the third position? The majority of subjects in this experiment judged the former event more likely despite the fact that there are three times as many words with a ' $K$ ' in the third position.

The shares of growth companies can be considered to be 'investment grade' shares which are closely followed by financial analysts and institutional investors. These shares receive wide coverage in the popular news media as well as in the investment literature. By contrast, shares of companies having less favourable growth prospects do not enjoy widespread attention by analysts and do not receive extensive press coverage. According to the availability heuristic, shares of growth companies are more likely to be selected for investment because they are more readily retrieved from the list of investment opportunities due to the prominence given to these securities in the investment literature. The shares of growth companies are favoured because they minimize the mental effort involved in decision-making. The less available the instances of an event, the harder it is to retrieve and construct them, and the lower the judged probability of that event.

Suppose that investors conclude, in error, that growth stocks are shares of growth companies. Can it be expected that they will learn from their errors? Kahneman \& Tversky (1982) observed an overwhelming tendency of experimental subjects to perpetuate their errors. Cognitive errors are reliable, systematic, and difficult to eliminate through experience. Kahneman \& Tversky also found that sophistication had a negligible effect on eliminating cognitive bias.

While we would expect that most investors will conclude that growth stocks are shares of growth companies, it cannot be expected that everyone will agree with this statement. In fact, followers of the theory of contrary opinion (contrarians) can be expected to reach the opposite conclusion. By definition, contrarians should be in the minority, vastly outnumbered by conventionals. Therefore, the trading strategies of contrarians do not exert sufficient force to eliminate the effects of trading by conventionals on share prices. In addition, it is difficult to tell a contrarian from a conventional by selfdescription. Many investors describe themselves as contrarians, even when their share selections expose them as conventionals.

Kahneman \& Tversky (1982) describe regret as frustration that comes when a person learns that a choice comes out badly. Choosing conventionally is a defense against regret. Investing in companies with high growth opportunities is the conventional choice of portfolio managers. Portfolio managers are often more comfortable to fail conventionally than to succeed unconventionally. The tendency to choose conventionally has been reported by Amott (1983) who observed that, 'no portfolio manager was ever fired for buying IBM'.

\section{Conclusion}

Growth companies are companies with the management ability and the opportunities to invest in projects that yield returns greater than the company's required rate of return on capital. Using Tobin's q, the ratio of the market value of the securities of a company to the replacement value of the assets, as a measure of growth opportunities, it was observed that shares of high growth companies provided inferior returns for companies listed on the JSE during the period 1974-1988. There is a positive relationship between Tobin's $\mathrm{q}$ and the market value of equity, and a positive relationship between Tobin's $q$ and the price-earnings ratio. But Tobin's $q$ does not allow us to distinguish shares with high returns from shares with low returns any better than the market value of equity or the price-earnings ratio.

Based on evidence in cognitive psychology it is suggested that the heuristics of representativeness and availability may influence investors to identify growth stocks as shares of growth companies. The vast majority of investors are 'conventionals' who prefer shares of growth companies because they erroneously conclude that growth stocks are shares of growth companies. Investing in shares of companies with high growth opportunities is the conventional choice of portfolio managers. Choosing conventionally is a defense against regret and it also minimizes the mental effort involved in decision-making. 'Contrarians' do not commit that error, yet their share holding and trading strategies do not exert sufficient force to eliminate the effects of trading by conventionals on share prices.

Over time, company results have a tendency to regress to the mean as the underlying economic forces attract new entrants to attractive markets and encourage participants to leave low growth businesses. Because of this tendency, companies that have provided high growth in the past may prove to be inferior investments, while low growth companies frequently provide superior investment returns in the future. The high growth companies underperform because the market often overestimates their future growth and future return on equity and, as a result, accords the shares overvalued priceearnings ratios. The converse is true of companies currently experiencing poor growth prospects. 
Traditionally, security analysts and investors seek growth companies in the belief that they will tend to be good investments. However, empirical evidence has shown that neither financial attributes nor behavioural attributes can guarantee superior investment returns in the future. The investor should integrate a rigorous valuation model into the share selection procedure so that estimates of future growth and profitability can be used to make an explicit estimate of expected return. Buying at any price and hoping that the superior returns will be perpetuated will often produce disappointing results.

\section{References}

Amoth, R.D. 1983. 'What hath MPT wrought: Which risks reap rewards?' Journal of Portfolio Management, Vol. 9: 5-11.

Bemstein, P.L. 1956. 'Growth companies versus growth stocks.' Harvard Business Review, September, 87-98.

Bowman, R.C. 1983. 'Understanding and conducting event studies.' Journal of Business Finance and Accounting, Vol. 10: 561-584.

Clayman, M. 1987. 'In search of excellence: The investor's viewpoint.' Financial Analysts Journal, May-June, 54-63.

Fisher, F. \& McGowan, J. 1983. 'On the misuse of accounting rates of retum to infer monopoly profits.' American Economic Review, Vol. 73: 82-97.

Kahneman, D. \& Tversky, A. 1972. 'Subjective probability: A judgment of representativeness.' Cognitive Psychology, Vol. 3: $430-454$.
Kahneman, D. \& Tversky, A. 1982. Judgment under unceriainty: Heuristics and biases. New York: Cambridge University Press.

Keim, D.B. \& Stambaugh, R.F. 1986. 'Predicling returns in the stock and bond markets.' Journal of Financial Economics, Vol. 14: 357-390.

Lindenberg, E.B. \& Ross, S.A. 1981. 'Tobin's q ratio and industrial organisation.' Journal of Business, Vol. 54: 1-32.

Malkiel, B.G., Von Furstenberg, G.M. \& Watson, H.S. 1979. 'Expectations, Tobin's q and industry investment.' Journal of Finance, Vol. 34: 549-564.

Miller, M.H. \& Modigliani, F. 1961. 'Dividend policy, growth and the valuation of shares.' Journal of Business, Vol. 34: 411-433.

Peters, T.J. \& Waterman, R.H. Jr. 1982. In search of excellence: Lessons from America's best-run corporations. New York: Harper \& Row Publishers.

Reilly, F.K. 1971. 'A differentiation between types of companies and types of stock.' Mississippi Valley Journal of Business and Economics, Vol. 7: 35-43.

Smalter, D.J. \& Lancey, R.C. 1966. 'P/E analysis in acquisition strategy.' Harvard Business Review, Vol. 44: 85-95.

Solt, M.E. \& Statman, M. 1989. 'Good companies, bad stocks.' Journal of Portfolio Management, Vol. 15: 39-44.

Tobin, J. 1969. 'A general equilibrium approach to monetary theory.' Journal of Money, Credit and Banking, February, 15-29. 